\title{
PRZERWANIE BIEGU PRZEDAWNIENIA ROSZCZEŃ PRZEZ WSZCZĘCIE MEDIACJI
}

Wprowadzając w 2005 r. ${ }^{1}$ unormowania dotyczące mediacji do Kodeksu postępowania cywilnego, ustawodawca przewidział także powiązane z ta instytucja stosowne zmiany w innych aktach prawnych. Jedna z nich było dodanie w art. $123 \S 1$ k.c. nowej, trzeciej przyczyny przerwania biegu przedawnienia roszczeń, właśnie w postaci wszczęcia mediacji ${ }^{2}$. Wobec tak zwięzłego ujęcia tego sposobu przerwania biegu przedawnienia można by odnieść wrażenie, że w tym przypadku klarowne będzie, czy i kiedy dochodzi do tego przerwania. Na tym tle zauważyć należy, że dotychczas przewidywane w Kodeksie cywilnym przyczyny przerwania biegu przedawnienia okazały się nie dostarczać w tej kwestii niebudzacych watpliwości kryteriów kwalifikacyjnych. Wystarczy wspomnieć o narosłych wokół art. $123 \S 1$ pkt 1 k.c. sporach doktrynalnych i wcale niejednolitej linii orzeczniczej. Mianowicie w tym ostatnim przepisie przewiduje się przerwanie biegu przedawnienia poprzez czynność podjętą przed sądem lub innym organem powołanym do rozpoznawania spraw lub egzekwowania roszczeń danego rodzaju albo przed sadem polubownym, przedsięwziętą bezpośrednio w celu dochodzenia lub ustalenia albo zaspokojenia lub zabezpieczenia roszczenia. $\mathrm{Na}$ tym tle w odniesieniu do niektórych czynności przedmiotem nieustających kontrowersji pozostaje, czy powoduja one przerwanie biegu przedawnienia roszczeń, czy też nie.

${ }^{1}$ Na podstawie ustawy z 28 lipca 2005 r. o zmianie ustawy - Kodeks postępowania cywilnego oraz niektórych innych ustaw (Dz. U. Nr 172, poz. 1438), która weszła w życie 10 grudnia 2005 r.

${ }^{2}$ Przy czym dotyczy to mediacji w ujęciu wasskim (Z. Milczek, Mediacja w sprawach cywilnych, „Przegląd Prawa Handlowego” 2006, nr 6, s. 11). Zgodnie z jednocześnie odpowiednio zmienionym art. $124 \S 2$ k.c. w razie przerwania przedawnienia przez wszczęcie mediacji przedawnienie nie biegnie na nowo, dopóki zainicjowane w tej sposób postępowanie nie zostanie zakończone (zob. R. Morek, Mediacja i arbitraż. Art. $183^{1}-183^{15}$, 1154-1217 KPC. Komentarz, Warszawa 2006, s. 69). W literaturze przedmiotu podniesiono, że charakterowi mediacji lepiej odpowiadałoby zawieszenie na czas jej trwania biegu terminu przedawnienia, aniżeli zastrzeganie przerwania tego ostatniego w wyniku wszczęcia mediacji (P. Chańko, T. Strumiłło, Przerwanie biegu terminu przedawnienia na skutek wszczęcia mediacji, „ADR. Arbitraż i Mediacja” 2010, nr 1, s. 54). Jak się jednak wydaje, rozwiązanie wybrane przez polskiego ustawodawcę lepiej komponuje się z dotychczasowymi unormowaniami dotyczącymi zakłócania biegu przedawnienia (wszczęcie mediacji bliższe jest konstrukcyjnie innym przyczynom przerwania biegu przedawnienia, aniżeli tym powodującym jego zawieszenie), a nadto było dopuszczalne w świetle pkt 24 preambuły i art. 8 dyrektywy Parlamentu Europejskiego i Rady 2008/52/WE z 21 maja 2008 r. w sprawie niektórych aspektów mediacji w sprawach cywilnych i handlowych (OJ L 136 z 24 maja 2008 r.), która nie przesądza nic o tym, która z tych konstrukcji - przerwanie czy zawieszenie biegu terminu przedawnienia - ma tu wchodzić w grę, wskazując tylko cel do osiagnięcia za pomocą którejś z nich. 
Zasadnicze spory oscylują wokół sposobu pojmowania postawionego w powołanym przepisie wymogu, by dana czynność była przedsięwzięta bezpośrednio celem dochodzenia, ustalenia, zaspokojenia lub zabezpieczenia roszczenia. Część autorów, powołując się na słownikowe wyjaśnienia słowa „bezpośrednio", opowiada się za przyjmowaniem, że przerywają bieg przedawnienia roszczeń tylko takie czynności, które same, tj. bez potrzeby podejmowania jeszcze jakichkolwiek innych kroków, doprowadzą do osiąnnięcia któregoś z wymienionych celów ${ }^{3}$. Inni z kolei optują za tym, że za przerywające bieg przedawnienia na podstawie art. $123 \S 1$ pkt 1 k.c. należy uznawać takie czynności, których pominięcie w dążeniu do dochodzenia i egzekwowania roszczenia nie jest możliwe, a przy tym po podjęciu danej czynności aż do zakończenia zainicjowanego nią postępowania wierzyciel nie ma możliwości prawnie skutecznego inicjowania dalszych działań na drodze do dochodzenia lub egzekwowania roszczenia, którego dotyczyła ta czynność ${ }^{4}$.

Konsekwencją tej rozbieżności poglądów są spory m.in. w tak istotnych dla praktyki kwestiach, jak to, czy przerwaniem biegu przedawnienia skutkuje złożenie wniosku o nadanie klauzuli wykonalności tytułowi egzekucyjnemu ${ }^{5}$. Ponadto na gruncie art. $123 \S 1$ pkt 1 k.c. problematyczne pozostaje też np., czy dochodzi do przerwania biegu przedawnienia na skutek wniesienia pozwu do sądu powszechnego w razie, gdy strony wcześniej sporządziły zapis na sąd polubowny ${ }^{6}$. Watpliwości narosły również wokół drugiej statuowanej w Kodeksie cywilnym przyczyny przerwania biegu przedawnienia roszczeń, tj. uznania roszczenia przez osobę, przeciwko której ono przysługuje (art. $123 \S 1$ pkt 2 k.c.), zwłaszcza w kontekście konstrukcji uznania niewłaściwego i kwestii dotyczacych uznania dokonywanego przez osobę prawną?

${ }^{3}$ Tak m.in. Z. Klafkowski, Przedawnienie $w$ prawie cywilnym, Warszawa 1970, s. 151; P. Machnikowski, w: E. Gniewek, P. Machnikowski (red.), Kodeks cywilny. Komentarz, Warszawa 2014, s. 287.

${ }^{4}$ B. Kordasiewicz, w: System prawa prywatnego, t. 2: Prawo cywilne-część ogólna, red. Z. Radwański, Warszawa 2008, s. 653; Ł. Błaszczak, J. Kuźmicka-Sulikowska, Wniosek o nadanie klauzuli wykonalności i wniosek o stwierdzenie wykonalności a przerwanie biegu przedawnienia roszczeń, „Polski Proces Cywilny” 2012, nr 2, s. 231.

${ }^{5}$ Przeciwni temu sa m.in. A. Brzozowski, w: K. Pietrzykowski (red.), Kodeks cywilny, t. 1: Komentarz do artykutów 1-44911, Warszawa 2008, s. 536; M. Muliński, Czy wniosek o nadanie klauzuli wykonalności tytułowi egzekucyjnemu przerywa bieg przedawnienia?, „Monitor Prawniczy” 2003, nr 2, s. 95; P. Machnikowski, op. cit., s. 289; J. Pardus, B. Pardus, Złożenie wniosku o nadanie tytułowi egzekucyjnemu klauzuli wykonalności nie przerywa biegu przedawnienia roszczenia, „Radca Prawny” 2013, nr 141, s. 2D. Z kolei za tym, że dochodzi wówczas do przerwania biegu przedawnienia, opowiadaja się np. B. Kordasiewicz, op. cit., s. 653; S. Rudnicki, aktualizacja R. Trzaskowski, w: J. Gudowski (red.), Kodeks cywilny. Komentarz. Część ogólna, Warszawa 2014, s. 844; Ł. Błaszczak, J. Kuźmicka-Sulikowska, op. cit., s. 231-232; tak też w nowszym orzecznictwie, m.in. w: uchwale SN z 16 stycznia 2004 r., III CZP 101/03, OSNC 2005, nr 4, poz. 58; wyroku SN z 4 października 2012 r., I CSK 90/12, Lex, nr 1250551; wyroku SA w Lublinie z 29 stycznia 2014 r., I ACa 684/13, Lex, nr 1439236.

${ }^{6}$ Zob. J. Kuźmicka-Sulikowska, Zapis na sqd polubowny i postepowanie przed tym sqdem a przerwanie biegu przedawnienia roszczeń, „ADR. Arbitraż i Mediacja” 2010, nr 4, s. 17-38.

${ }^{7}$ Zob. np. M. Pyziak-Szafnicka, Przerwanie biegu przedawnienia przez uznanie, „Rejent” 1993, nr 9, s. 32-49; eadem, Uznanie długu, Łódź 1995, s. 106-191; A. Szpunar, Wptyw uznania na bieg przedawnienia, „Nowe Prawo” 1973, nr 7-8, s. 997-1010; J. P. Naworski, Przerwa biegu przedawnienia na skutek uznania niewłaściwego przez dtużnika będqcego osoba prawna, cz. I, 
W porównaniu z powyższym użyte przez ustawodawcę w art. $123 \S 1$ pkt 3 k.c. sformułowanie, w myśl którego bieg przedawnienia przerywa się przez wszczęcie mediacji, zdaje się, przynajmniej w warstwie językowej, nie budzić większych wątpliwości. Jednak dla oceny, czy rzeczywiście tak jest, a więc czy da się w każdym przypadku jednoznacznie wskazać moment wszczęcia mediacji, niezbędne jest też poddanie analizie unormowań dotyczących mediacji, które, jak już wspomniano, zawarte są w Kodeksie postępowania cywilnego.

W przypadku postępowania mediacyjnego inicjowanego przez stronę wydawać by się mogło, że ustawodawca precyzyjnie określił moment, w którym dochodzi do przerwania biegu przedawnienia. Zgodnie z art. $123 \S 1$ pkt 3 k.c. następuje to bowiem przez wszczęcie mediacji, a to ostatnie z kolei, w myśl art. $183^{6} \S 1$ k.p.c., zachodzi z chwilą doręczenia mediatorowi wniosku o przeprowadzenie mediacji, z dołaczonym dowodem doręczenia jego odpisu drugiej stronie. Niemniej należy od razu zauważyć, że nie zawsze będzie wówczas dochodziło do wszczęcia mediacji, a co za tym idzie - przerwania biegu przedawnienia. Wynika to z tego, że w art. $183^{6} \S 2$ k.p.c. ustawodawca przewidział cały szereg przypadków, w których pomimo prawidłowego doręczenia wspomnianego wyżej wniosku nie będzie dochodzić do wszczęcia mediacji. Przy tym o ile jawią się one jako uzasadnione w świetle zasad rządzących mediacja, o tyle nie do końca przystaja do prawnomaterialnej konstrukcji przedawnienia $^{8}$. Nie będzie bowiem dochodzić do wszczęcia mediacji, jeśli stały mediator $\mathrm{w}$ terminie tygodnia od doręczenia mu wniosku o przeprowadzenie mediacji odmówi podjęcia się tego zadania (art. $183^{6} \S 2$ pkt 1 k.p.c.), lub jeśli identycznie w tym samym terminie postapi osoba niebędąca stałym mediatorem, która strony wskazały jako mediatora w zawartej przez siebie umowie o mediację (art. $183^{6} \S 2$ pkt 2 k.p.c.) albo - jeśli strony zawarły umowę o mediację bez wskazania mediatora, a osoba, do której strona zwróciła się o przeprowadzenie mediacji w terminie tygodnia od doręczenia jej wniosku o przeprowadzenie mediacji, nie wyraziła zgody na jej przeprowadzenie bądź druga strona w terminie tygodnia nie wyraziła zgody na osobę mediatora (art. $183^{6} \S 2$ pkt 3 k.p.c.). Wszczęcie mediacji nie będzie następowało pomimo doręczenia wniosku o przeprowadzenie mediacji zgodnie $\mathrm{z}$ wymogami z art. $183^{6} \S 1$ k.p.c. także w sytuacji, gdy strony nie zawarły uprzednio umowy o mediację, a druga strona zgody na mediację nie wyraziła (art. $183^{6} \S 2$ pkt 4 k.p.c.).

Jak wynika z powyższego, w szeregu przypadków, pomimo doręczenia mediatorowi wniosku o przeprowadzenie mediacji, z dołączonym dowodem doręczenia jego odpisu drugiej stronie (a więc dopełnienia wymogów z art. $183^{6}$ $\S 1$ k.p.c.), nie będzie dochodziło do wszczęcia mediacji, a w konsekwencji przerwania biegu przedawnienia (art. $123 \S 1$ pkt 3 k.c.), z uwagi na brak zgo-

\footnotetext{
„Monitor Prawniczy” 2004, nr 18, s. 840-846; A. Stępień-Sporek, Kilka uwag o uznaniu niewtaściwym, „Gdańskie Studia Prawnicze” 2010, t. 24, s. 197-205.

${ }_{8}$ To, że ten ostatni powołany przepis będzie niósł ze sobą problemy interpretacyjne, choć bez bliższego wskazania jakie, sygnalizowano od razu po jego wejściu w życie (M. Białecki, Praktyczne aspekty mediacji jako alternatywnej formy rozstrzygania sporów w sprawach rodzinnych-analiza prawnoporównawcza, „Palestra” 2006, nr 9-10, s. 41; zob. też: K. Wawrzyniak, Bieg terminu przedawnienia roszczeń $w$ przypadku wszczęcia mediacji na przyktadzie prawa polskiego oraz dyrektywy 2008/52/WE, „Przegląd Prawniczy Uniwersytetu Warszawskiego” 2009, nr 3-4, s. 226).
} 
dy na przeprowadzenie mediacji ze strony mediatora lub osoby, która strona (bądź strony) chciałyby powołać do pełnienia funkcji mediatora (art. $183^{6} \S 2$ pkt 1-3 k.p.c.). W rezultacie mamy tu więc do czynienia z sytuacjami, w których powstanie skutku materialnoprawnego w postaci przerwania biegu przedawnienia roszczenia uzależnione zostało od woli osoby trzeciej. Oceniając to rozwiązanie przez pryzmat konstrukcji przedawnienia, nie wydaje się ono właściwe. Jak dotąd ustawodawca słusznie uzależniał wystapienie skutku w postaci przerwania biegu przedawnienia jedynie od podjęcia określonych działań przez którąś ze stron stosunku prawnego, z którego dane roszczenie wynika, tj. albo od poczynienia stosownych kroków przez wierzyciela (art. $123 \S 1$ pkt 1 k.c.) albo od uznania roszczenia przez dłużnika (art. $123 \S 1$ pkt 2 k.c.). Natomiast z rozwiązania przyjętego na gruncie art. $123 \S 1$ pkt 3 k.c. w zw. z art. $183^{6}$ $\S 2$ pkt 1-3 k.p.c. wyłania się konstrukcja, w ramach której pomimo podjęcia przez wierzyciela wszystkich wymaganych kroków celem zainicjowania mediacji, jest on pozbawiony wpływu na to, czy dojdzie do jej wszczęcia, tzn. jego działanie w tym zakresie nie jest przesądzajace, ostatecznie bowiem zdecyduje tu czynnik pozostajacy poza wpływem wierzyciela, a mianowicie to, czy osoba trzecia podejmie się prowadzenia mediacji w danej sprawie. Co prawda stały mediator może odmówić prowadzenia mediacji jedynie z ważnych powodów (art. $183^{2} \S 4$ k.p.c.), to jednak gdyby odmówił, a następnie ujawniono by, że taki ważny powód ku temu nie zachodził, może to wywierać konsekwencje w innych sferach niż przedawnienie roszczeń. Mianowicie może stanowić podstawę np. do usunięcia takiej osoby z listy stałych mediatorów określonej instytucji, czy nawet dochodzenia odpowiedzialności odszkodowawczej mediatora przez stronę ${ }^{9}$, ale nie spowoduje potraktowania tej sytuacji jako skutkujacej przerwaniem biegu przedawnienia roszczeń.

Jeśliby więc w tym czasie (tj. pomiędzy doręczeniem przez wierzyciela wniosku o przeprowadzenie mediacji a niezasadna odmowa jej poprowadzenia przez stałego mediatora) miną termin przedawnienia, nie dojdzie (z uwagi na brak podstaw normatywnych ku temu) do sanowania tej czynności wierzyciela jako powodujaccej przerwanie biegu terminu przedawnienia; ten ostatni upłynie tu w sposób niezakłócony. Wówczas co najwyżej wierzyciel będzie mógł próbować dochodzić z tego tytułu wspomnianych roszczeń odszkodowawczych od mediatora ${ }^{10}$, w razie zaistnienia przesłanek odpowiedzialności tego ostatniego. Oczywiście jeśli do czasu odmowy przeprowadzenia mediacji przez mediatora termin przedawnienia spornego roszczenia nie upłynął, otwarta pozostaje dla wierzyciela droga dochodzenia tego roszczenia od dłużnika przed sądem powszechnym. Na tym tle należy też zaznaczyć, że powyżej wskazanych ograniczeń, jeśli chodzi o podjęcie się roli mediatora, nie doznaje osoba, która

\footnotetext{
${ }_{9}^{9}$ J. Kuźmicka-Sulikowska, Podstawa prawna odpowiedzialności cywilnej mediatora, „ADR. Arbitraż i Mediacja” 2008, nr 3, s. 88-90.

${ }^{10} \mathrm{~W}$ razie pozwania dłużnika ten ostatni będzie mógł bowiem podnieść zarzut przedawnienia roszczenia. Oczywiście należy mieć na uwadze, że w praktyce orzeczniczej nieraz dochodzi do kwalifikowania takiego zarzutu jako nadużycia prawa w rozumieniu art. 5 k.c. (i w rezultacie zasądzania roszczeń przedawnionych), w rozważanym przypadku trudno jednak raczej dopatrzyć się okoliczności analogicznych do tych, które z reguły traktowane są jako uzasadniające taka kwalifikację.
} 
nie jest stałym mediatorem. Jest to rozwiązanie jak najbardziej adekwatne, nie może być ona bowiem obowiązana do czegoś na mocy umowy innych podmiotów, zwłaszcza jeśli nie wyrażała wcześniej zgody na podjęcie się funkcji mediatora w ewentualnym sporze pomiędzy danymi stronami (np. w drodze umowy z nimi), ani nawet gotowości do pełnienia funkcji mediatora poprzez wpis na listę stałych mediatorów. Nie umniejsza to jednak faktu, że z punktu widzenia unormowań dotyczących przedawnienia przez tydzień zachodzić będzie niepewność co do tego, czy nastapi wszczęcie mediacji (czy osoba ta podejmie się roli mediatora), a co za tym idzie - czy nastapi przerwanie biegu przedawnienia (a jeśliby w ciagu tego tygodnia mijał właśnie termin przedawnienia, powstaje ryzyko po stronie wierzyciela, że jego roszczenie ulegnie przedawnieniu).

Co więcej, prócz powyższego ustawodawca przewidział tu też konstrukcję, w ramach której to, czy zgodne z art. $183^{6} \S 1$ k.p.c. złożenie przez wierzyciela wniosku o przeprowadzenie mediacji doprowadzi do jej wszczęcia, uzależnione zostało od postawy drugiej strony - dłużnika ${ }^{11}$. Rozwiązanie to oczywiście jest zasadne, jeśli rozpatrywać je w kontekście zasady dobrowolności mediacji. Zapobiega ono bowiem przymuszaniu drugiej strony do mediacji w przypadkach, gdy wcześniej w ogóle nie doszło do zawarcia umowy o mediację (art. $183^{6}$ $\S 2$ pkt 4 k.p.c.) bądź do poddania się mediacji prowadzonej przez osobę, której strony wcześniej nie wybrały na mediatora, a druga strona jej w tej roli nie akceptuje (art. $183^{6} \S 2$ pkt 3 k.p.c.). Jeżeli jednak spojrzeć na te regulacje przez pryzmat działania mechanizmu przedawnienia, to jawią się już one jako godzące w jego elementarny sens. Wszak chodzi w nim o to, że wierzyciel podejmuje określoną czynność celem dochodzenia roszczenia, przerywając tym samym bieg terminu przedawnienia, co ze swej istoty stanowi jednocześnie czynność podejmowaną przeciwko dłużnikowi (art. $123 \S 1$ pkt 1 k.c.). Podobnie w rozważanym przypadku wierzyciel inicjuje mediację celem uzyskania zaspokojenia przysługującego mu roszczenia (z tym że korzystając z dawanej przez ustawodawcę alternatywnej wobec sądowej metody rozstrzygania sporów), co wobec powyższego również powinno być powiązane z przerwaniem biegu przedawnienia. To jednak, czy do tego ostatniego skutku materialnoprawnego dojdzie, uzależnione zostało od swobodnej woli dłużnika, tj. od tego, czy zgodzi się on na osobę mediatora (art. $183^{6} \S 2$ pkt 3 k.p.c.) czy w ogóle przeprowadzenie mediacji (art. $183^{6} \S 2$ pkt 4 k.p.c.). Swojej decyzji w tych kwestiach dłużnik nie musi przy tym w żaden sposób uzasadniać, w tym istnieniem jakichś ważnych przyczyn przemawiających za ich podjęciem.

Dłużnik wcale nie musi się tu więc kierować jakimiś względami merytorycznymi, lecz właśnie jedynie chęcią niedopuszczenia do przerwania biegu przedawnienia (zwłaszcza jeśli w czasie danym mu przez ustawodawcę na

\footnotetext{
11 Odwrotna konfiguracja podmiotowa nie budzi bowiem z punktu widzenia przerwania biegu przedawnienia zastrzeżeń. Jeśli bowiem to dłużnik inicjuje przeprowadzenie mediacji, to tym samym sam generuje powstanie zdarzenia, które może przerwać bieg terminu przedawnienia wtedy to już od decyzji zainteresowanego tym przerwaniem wierzyciela zależy to, czy zgodzi się na osobę mediatora lub mediację w ogóle i w ten sposób doprowadzi do przerwania biegu przedawnienia, czy też ten ostatni skutek będzie chciał osiagnąć w inny sposób (np. wytaczając powództwo).
} 
podjęcie powyższych decyzji mijałby właśnie termin przedawnienia przysługującego przeciwko niemu roszczenia). Mamy tu zatem do czynienia z dość kuriozalnym rozwiązaniem, w ramach którego przerwanie biegu przedawnienia roszczenia w wyniku czynności podjętej przez wierzyciela zależy od woli tego, przeciwko komu roszczenie to przysługuje; to tak, jakby przerwanie biegu przedawnienia na skutek wniesionego przez wierzyciela pozwu uzależniać od tego, czy dłużnik zgodzi się zostać pozwanym. Jedyne, co pozwala ewentualnie próbować bronić to nieadekwatne z punktu widzenia mechanizmu przerywania przedawnienia rozwiązanie, to zakreślenie przez ustawodawcę bardzo krótkiego czasu na wspomnianą dyskrecjonalną decyzję dłużnika ${ }^{12}$, gdyż tylko jednego tygodnia (art. $183^{6} \S 2$ pkt 3 k.p.c.). Co za tym idzie - w interesie wierzyciela nie leży podejmowanie prób zainicjowania mediacji, jeśli do końca terminu przedawnienia przysługujacego mu roszczenia pozostał tydzień lub mniej, lecz powinien on wówczas (chcąc mieć pewność, że roszczenie to się nie przedawni) wytoczyć o nie powództwo. Co więcej, nawet jeśli termin ten mija nieco później, powinien uważać, by wystapić na czas do sądu ze wspomnianym pozwem także w razie negatywnego ustosunkowania się przez dłużnika co do zaproponowanej osoby mediatora, zanim upłynie termin przedawnienia roszczenia, którego biegu wszak nie zakłóciła zakończona niepowodzeniem próba zainicjowania mediacji.

Uwagi te trzeba odnieść odpowiednio do sytuacji, w której strony nie zawarły umowy o mediację, i to do decyzji dłużnika należy, czy w ogóle wyrazi zgodę na mediację, z tym jednak zastrzeżeniem, że w takim przypadku nie można przyjąć wspomnianego powyżej tygodniowego terminu, ponieważ w regulującym opisana sytuację art. $183^{6} \S 2$ pkt 4 k.p.c. ustawodawca go nie zastrzega. Co prawda w literaturze przedmiotu proponuje się wobec tego, by przyjmować, że na gruncie tego ostatniego przepisu do wszczęcia mediacji będzie dochodzić tylko w razie, gdy druga strona wyrazi zgodę na mediację niezwłocznie ${ }^{13}$, to jednak wobec niedookreśloności tego ostatniego zwrotu i różnych jego interpretacji, także w orzecznictwie ${ }^{14}$, nie wydaje się, że jest to rozwiązanie adekwatne z punktu widzenia konieczności jasnego określenia, czy i kiedy dochodzi tu do przerwania biegu przedawnienia (w tym, po jakim terminie ten skutek materialnoprawny już niewątpliwie nie wejdzie w grę), zwłaszcza jeśli uwzględnić przy tym sytuację wierzyciela, który złożył wniosek o przeprowadzenie mediacji w ostatnich dniach terminu przedawnienia przysługującego mu roszczenia. Dlatego też, uwzględniając te kwestie wiążące się z przedawnieniem roszczeń, postulować należy precyzyjne wskazanie przez ustawodawcę w art. $183^{6} \S 2$ pkt 4 k.p.c. terminu, jaki ma druga strona na podjęcie decyzji co do zgody na mediację $e^{15}$. Natomiast na gruncie obowiąującego de lege lata brzmienia tego ostatniego przepisu nie sposób wobec powyższe-

12 Przy czym musi być ona wyraźnie zakomunikowana, nie domniemywa się jej z milczenia drugiej strony. Zob. A. Zieliński, w: idem (red.), Kodeks postepowania cywilnego. Komentarz, Warszawa 2014 , s. 371.

${ }^{13}$ P. Chańko, T. Strumiłło, op. cit., s. 51.

${ }_{14} \mathrm{Na}$ co słusznie zwraca uwagę, choć w innym kontekście, B. Kordasiewicz, op. cit., s. 655.

15 Podobny postulat, choć z innych przyczyn, zgłaszają też: P. Chańko, T. Strumiłło, op. cit., s. 51 . 
go stwierdzić, jaki czas przed upływem terminu przedawnienia wierzyciel co najmniej powinien zachować, występujac z wnioskiem o przeprowadzenie mediacji, by nie narażać się na ryzyko, że jego roszczenie ulegnie przedawnieniu w czasie podejmowania przez drugą stronę decyzji co do tego, czy zgadza się na mediację; czas ten obecnie oceniany będzie bowiem ad hoc przy uwzględnieniu okoliczności danego przypadku.

Ponadto zauważyć należy, że problem z ustaleniem, czy doszło do przerwania biegu przedawnienia, a jeśli tak, to kiedy, pojawiać się może także w sytuacjach, gdy nie zachodzi żaden z omówionych powyżej przypadków unormowanych w art. $183^{6} \S 2$ k.p.c., ale doręczony mediatorowi wniosek o przeprowadzenie mediacji (wraz $\mathrm{z}$ dowodem doręczenia jego odpisu drugiej stronie) nie będzie czynił zadość wymogom stawianym w art. $183^{7}$ k.p.c. Zgodnie z tym ostatnim przepisem bowiem wniosek taki powinien obejmować oznaczenie stron, dokładnie określone żądanie, przytoczenie okoliczności uzasadniających to żądanie, podpis strony oraz wymienienie załączników, a także - jeśli strony zawarły umowę o mediację na piśmie - odpis tej umowy. Z punktu widzenia regulacji łączącej z wszczęciem mediacji przerwanie biegu przedawnienia (art. 123 § 1 pkt 3 k.c.) szczególne znaczenie mają te dwa pierwsze wymienione wymagane elementy treści omawianego wniosku, a to z uwagi na możliwość określenia dzięki nim zarówno podmiotowego, jak i przedmiotowego zakresu, w jakim w wyniku złożenia takiego wniosku dochodzi do przerwania biegu przedawnienia (tj. jakie roszczenie, przysługujące komu i wobec kogo obejmie ten skutek materialnoprawny). Stąd zawarcie tych wymaganych informacji we wniosku o przeprowadzenie mediacji jawi się jako konieczność z punktu widzenia unormowania łączącego przerwanie biegu przedawnienia z wszczęciem mediacji. Jeśli jednak przyjrzeć się poglądom zgłaszanym w literaturze przedmiotu w odniesieniu do właściwego sposobu postępowania w sytuacji, w której wniosek o wszczęcie mediacji nie będzie zawierał wszystkich elementów wskazanych w art. $183^{7}$ k.p.c., okazuje się, że przyjmowane w tej kwestii stanowiska sa skrajnie odmienne, a co szczególnie istotne z uwagi na tematykę niniejszych rozważań - żadna z tych koncepcji nie wydaje się adekwatna w kontekście normatywnego powiązania ze wszczęciem mediacji przerwania biegu przedawnienia. Przechodząc do szczegółów, zauważyć należy, że według części autorów mamy wówczas do czynienia z brakiem formalnym ${ }^{16}$; niektórzy nawet, kwalifikując taki wniosek jako pismo procesowe, podnosza, że w razie niespełnienia przez wnioskodawcę wymogów stawianych w art. 126 k.p.c. i n. lub właśnie w art. $183^{7}$ k.p.c. zasadne jest zastosowanie przez przewodniczacego art. 130 k.p.c. ${ }^{17}$ Reprezentowane jest jednak także stanowisko zdecydowanie oponujace przeciwko kwalifikowaniu wniosku o przeprowadzenie mediacji jako pisma procesowego, a co za tym idzie - stosowaniu art. 130 k.p.c. w razie niezawarcia w tym wniosku któregoś z elementów wymienionych w art. $183^{7}$

16 T. Ereciński, Kilka uwag o mediacji w sprawach cywilnych, w: K. Szczepanowska-Kozłowska (red.), Oblicza prawa cywilnego. Księga jubileuszowa dedykowana Profesorowi Janowi Błeszyńskiemu, Warszawa 2013, s. 124.

17 I. Gil, Skutki prawne wszczęcia i przeprowadzenia mediacji w postepowaniu cywilnym i sqdowoadministracyjnym, w: J. Olszewski (red.), Sady polubowne i mediacja, Warszawa 2008, s. 87. 
k.p.c. ${ }^{18}$ Przy tym podawane sa różne koncepcje co do tego, czy i jakie konsekwencje wywołuje w takim razie taki niepełny wniosek. Według jednych autorów nie pociaga on wówczas za sobą żadnych skutków prawnych ${ }^{19}$, którą to radykalną konsekwencję łagodzi się nieco przez wskazywanie możliwości (ale nie obowiązku) wyznaczenia przez mediatora krótkiego terminu na uzupełnienie wniosku przez stronę pod rygorem odmowy przeprowadzenia mediacji ${ }^{20}$ (kwalifikując brak takiego jego uzupełnienia w terminie jako ważna przyczynę w rozumieniu art. $183^{2} \S 4$ k.p.c. do odmowy przeprowadzenia mediacji przez stałego mediatora $\left.{ }^{21}\right)$. Z kolei inni podnosza, że należy uszanować praktykę mediacji, w ramach której strony zgłaszaja się do mediatora z wolą rozwiązania konfliktu, a nie zestawem wymaganych przez przepisy ustawy dokumentów i zazwyczaj dopiero już w trakcie postępowania mediacyjnego wniosek jest odpowiednio do tych wymogów uzupełniany, jak też dochodzi do sprecyzowania, co stanowi przedmiot konfliktu22.

$\mathrm{Z}$ żadnym z tych poglądów nie można się jednak zgodzić. Przede wszystkim ten ostatni musi być odrzucony z uwagi na powiązanie przez ustawodawcę w treści art. $123 \S 1$ pkt 3 k.c., w drodze wspominanej już ustawy z 2005 r., wszczęcia mediacji ze skutkiem w postaci przerwania biegu przedawnienia roszczeń. Na potrzeby tego ostatniego musi być bowiem jasne w stosunku do jakiego roszczenia dochodzi do przerwania biegu przedawnienia, tak jak w odniesieniu do każdej innej czynności powodującej przerwanie biegu przedawnienia; w rozważanym przypadku brak jakichkolwiek podstaw normatywnych do czynienia odstępstwa od tej zasady ${ }^{23}$. Niedopuszczalne jest więc przyjmo-

${ }_{18}$ M. Skibińska, Mediacja w sprawach cywilnych - studium porównawcze na tle rozwiazań polskich $i$ francuskich, „Rejent” 2008, nr 3, s. 52; P. Malaga, A. Mól, Sposoby $i$ skutki wszczęcia mediacji, „ADR. Arbitraż i Mediacja” 2008, nr 4, s. 122; P. Chańko, T. Strumiłło, op. cit., s. 43.

${ }^{19}$ M. Skibińska, op. cit., s. 52.

${ }^{20}$ P. Chańko, T. Strumiłło, op. cit., s. 43; M. Skibińska, op. cit., s. 52.

${ }^{21}$ A. Zieliński, w: idem (red.), op. cit., s. 371; M. Sychowicz, w: K. Piasecki (red.), Kodeks postepowania cywilnego. Komentarz do artykułów 1-50514, t. 1, Warszawa 2006, s. 748.

${ }^{22}$ P. Malaga, A. Mól, op. cit., s. 122; V. Huryn, w: A. Gójska, V. Huryn, Mediacja w rozwiazywaniu konfliktów rodzinnych, Warszawa 2007, s. 305.

${ }^{23} \mathrm{~W}$ tym kontekście należy podkreślić, że ustawodawca zniósł wyjątek od tej zasady, gdyż na mocy art. 36 ust. 1 ustawy z 2 lipca 2004 r. o zmianie ustawy - Kodeks postępowania cywilnego oraz niektórych innych ustaw (Dz. U. Nr 172, poz. 1804) uchylił z moca od 5 lutego 2005 r. art. 321 $\S 2$ k.p.c., pozwalający uprzednio orzekać ponad żądanie w sprawach o roszczenia alimentacyjne i o naprawienie szkody wyrządzonej czynem niedozwolonym. De lege lata możliwość taka pozostała jedynie na gruncie art. $477^{1}$ k.p.c., gdzie w razie gdy pracownik dokonał wyboru jednego z przysługujących mu roszczeń, a okazało się ono nieuzasadnione, sąd może z urzędu uwzględnić inne roszczenie alternatywne (co należy podkreślić kompetencja ta została tu wyraźne zastrzeżona dla sądu, a zatem nie można jej przyznawać także mediatorowi w ramach mediacji w sporze ze stosunku pracy). Można oczywiście zauważyć, że pomimo braku wyraźnej podstawy ustawowej niekiedy w orzecznictwie przyjmuje się, że dochodzi do przerwania biegu przedawnienia roszczenia o zachowek w pełnej wysokości, choćby jego kwota żądana w pozwie była niższa (zob. np. wyrok SN z 17 kwietnia 2009 r., III CSK 298/08, „Biuletyn Sądu Najwyższego” 2009, nr 9, poz. 9), a także o całe odszkodowanie dochodzone z tytułu czynu niedozwolonego, w wysokości przekraczającej tę żądaną w pozwie (przy spełnieniu szeregu warunków, m.in. jeśli specyficzne cechy uszczerbku sprawiaja, że dopiero biegły będzie mógł ocenić wysokość szkody; zob. np. wyrok SN z 6 kwietnia 2011 r., I CSK 684/09, Lex, nr 951732). Jednak zauważyć należy, że taka linia orzecznicza budzi kontrowersje (w tym w świetle art. $321 \S 1$ k.p.c. i wobec uchylenia jego § 2), a nadto pojawiła się 
wanie, że przerwanie to następowałoby właściwie co do wszystkich roszczeń pomiędzy stronami konfliktu (z ewentualnym ich doprecyzowaniem już w czasie mediacji); również $\mathrm{z}$ tego powodu, że stanowiłoby to rozwiąanie w nieuzasadniony sposób preferujące w zbyt dużym stopniu interes wierzyciela w stosunku do interesu dłużnika. Z kolei stanowisko, w ramach którego swobodnej decyzji mediatora pozostawia się to, czy wezwie stronę do uzupełnienia braków wniosku o przeprowadzenie mediacji, a jeśli tak, to w jakim terminie, razi dowolnością i różnicowaniem w ten sposób sytuacji prawnej podmiotów z uwagi na czynnik zupełnie przygodny. Jednemu wierzycielowi określony mediator nie dałby bowiem możliwości uzupełnienia takiego wniosku, wskutek czego, według zwolenników tego poglądu, wniosek ten nie wywołałby żadnych skutków prawnych (i co tu istotne - nie spowodowałby przerwania biegu przedawnienia roszczeń), a z kolei drugiemu inny mediator dałby szansę na takie uzupełnienie. Zresztą w tym ostatnim przypadku pojawiałyby się dalsze problemy, w tym to, czy w razie uzupełnienia wniosku przerwanie biegu przedawnienia łączyć z datą tego uzupełnienia, czy z dniem złożenia pierwotnego wniosku.

Jak się wydaje, skoro zwolennicy tego stanowiska odrzucają stosowanie art. 130 k.p.c., a więc także jego § 3, to przerwanie biegu przedawnienia następowałoby dopiero z momentem właściwego uzupełnienia tego wniosku. Takie zapatrywanie implikowałoby też powstanie problemów z oceną sytuacji, gdy termin przedawnienia roszczenia upłynął po złożeniu pierwotnego wniosku, ale przed terminem wyznaczonym na jego uzupełnienie przez mediatora ${ }^{24}$. Teoretycznie jako rozwiązanie wielu tych wątpliwości, w tym zwłaszcza wspomnianego powyżej bezzasadnego różnicowania sytuacji podmiotów w zależności od tego, czy dany mediator będzie wzywał o uzupełnienie braków wniosku o przeprowadzenie mediacji, czy też nie, zapobiegłoby stosowanie w razie braków formalnych tego wniosku art. 130 k.p.c., a więc rozwiązanie proponowane $\mathrm{w}$ ramach pierwszego z powołanych powyżej poglądów. Uznać jednak należy, że de lege lata nie ma ku temu podstaw normatywnych. Trzeba bowiem zgodzić się z tym, że wniosek o przeprowadzenie mediacji nie jest pismem procesowym i już z tej przyczyny nie jest objęty zakresem zastosowania art. 130 k.p.c. Nie jest on w ogóle wnoszony do sądu, lecz doręczany przez stronę mediatorowi; na stronie wnioskującej o przeprowadzenie mediacji ciąży też obowiązek doręczenia odpisu tego wniosku drugiej stronie. Brak tu zatem po prostu także faktycznej możliwości kontroli kompletności tego wniosku przez przewodniczącego i ewentualnego wzywania o jego uzupełnienie. Wobec od-

tylko w przypadkach znamionujących się szczególnymi okolicznościami poważnie utrudniającymi czy wręcz uniemożliwiającymi określenie wysokości roszczenia, których brak w przypadku mediacji, w każdym razie dotyczącej innych roszczeń. Ponadto nigdy nie dopuszcza się w tym orzecznictwie przerwania przedawnienia wszystkich roszczeń pomiędzy danymi stronami, a co najwyżej podanego przez stronę rodzaju roszczenia w wyższej niż pierwotnie wskazana przez nią wysokości.

${ }^{24} \mathrm{~W}$ tym jeśli chodzi o wątpliwości co do odpowiedzialności odszkodowawczej mediatora z tego tytułu, skoro wobec braków wniosku mógł nie mieć podstaw do dokonania oceny, o jakie roszczenie, a co za tym idzie - podlegające jakiemu terminowi przedawnienia, powstał między stronami spór, ani też czy i kiedy stało się ono wymagalne itd. 
mienności sytuacji nie można także stosować art. 130 k.p.c. w drodze analogii. Przeciwko temu ostatniemu rozwiązaniu przemawia też zresztą rygoryzm potencjalnych skutków (zob. art. 130 § 2 k.p.c.), których nie sposób przyjmować wobec braku wyraźnej podstawy normatywnej ku temu, a także to, że przy takim analogicznym stosowaniu wspomnianego przepisu oceny kompletności wniosku dokonywałby mediator, który przecież nie musi być (i często nie jest) prawnikiem, i to jeszcze o kompetencjach sędziego, by w każdym przypadku dawać rękojmię dokonania prawidłowej oceny, czy wniosek ten ma braki oraz właściwego wskazania, co i jak strona ma wobec tego uzupełnić.

Brak podstawy do stosowania de lege lata art. 130 k.p.c. do wniosku o przeprowadzenie mediacji nie oznacza jednak, że nie należy postulować jej wprowadzenia przez ustawodawcę de lege ferenda. Rozwiązałoby to bowiem przedstawione powyżej spory co do skutków prawnych braków formalnych wniosku o przeprowadzenie mediacji, a co najistotniejsze - pozwoliło ustalić na potrzeby praktyki stosowania prawa konsekwencje takiej sytuacji, nie narażając poszczególnych wnioskodawców na odmienne traktowanie w zależności od przyjęcia któregoś z funkcjonujących w tym zakresie poglądów.

Jak wykazano powyżej, jest to m.in. szczególnie istotne właśnie w kontekście potrzeby uzyskania niebudzącego wątpliwości kryterium oceny, czy w razie takich braków dochodzi do wszczęcia mediacji czy też nie, czy jest obowiązek wzywania o uzupełnienie braków wspomnianego wniosku i czy w razie tego uzupełnienia dochodzi do przerwania biegu przedawnienia, a jeśli tak, to kiedy. Normatywne wprowadzenie stosowania w rozważanym przypadku art. 130 k.p.c. przyniosłoby ze sobą jednakowe traktowanie wszystkich składających takie wnioski, dawałoby możliwość ratowania sytuacji w razie niezawarcia we wniosku wszystkich elementów z art. $183^{7}$ k.p.c., dając możliwość ich uzupełnienia, a wobec uzupełnienia - pozwoliło jednoznacznie określić zaistnienie zdarzenia powodujacego przerwanie biegu przedawnienia i jego momentu (w dacie pierwotnie złożonego wniosku). Nie oznacza to jednak, że rozwiązanie takie nie niosłoby za sobą żadnych potencjalnych mankamentów. Zauważyć bowiem należy, że teoretycznie wchodzą tu w grę dwie możliwości, tj. albo wprowadzenie stosowania art. 130 k.p.c. jedynie odpowiednio przy przyznaniu w odniesieniu do wniosku o przeprowadzenie mediacji kompetencji zastrzeżonych w tym przepisie dla przewodniczącego mediatorowi, albo zastrzeżenie stosowania art. 130 k.p.c. wprost, a więc włączenie przewodniczącego w ocenę formalną wniosku o przeprowadzenie mediacji.

Wobec pierwszego z tych rozwiązań można jednak mieć obiekcje dlatego, że jak już sygnalizowano, często mediatorem będzie osoba niemająca odpowiedniej wiedzy prawniczej do prawidłowej oceny spełnienia przez taki wniosek wymogów formalnych (a nawet doświadczenia - zwłaszcza jeśli chodzi o osobę, którą strony będą chciały ad hoc powołać do pełnienia funkcji mediatora w swoim sporze), a nadto w powoływanej już literaturze przedmiotu podnosi się, że nawet obecnie w praktyce mediacji - pomimo wspominanego prawnego jej uregulowania w 2005 r. - do tych aspektów formalnych nie przywiąuje się wagi, a sporne roszczenie doprecyzowuje się już w czasie mediacji, co de lege lata jawi się jako niedopuszczalne z uwagi na powiązanie ze wszczęciem 
mediacji skutku w postaci przerwania biegu przedawnienia. Dlatego też jeśli uwzględniać potrzeby tej ostatniej instytucji prawnej, preferować należałoby drugie ze wskazanych rozwiązań (tj. normatywne ustanowienie stosowania tu art. 130 k.p.c. wprost, z formalną oceną wniosku przez przewodniczącego), a przeciwko niemu nie powinno przemawiać włączenie tu sądu. Przecież i tak bywa on tu włączony, gdyż ugoda zawarta przed mediatorem wymaga zatwierdzenia przez sąd, by zyskała moc prawną ugody zawartej przed sądem; podlega przy tym kontroli merytorycznej (art. $183^{14}, 183^{15}$ k.p.c.).

Przy wprowadzeniu tego rozwiązania jednak wierzyciel, chcąc uniknąć ryzyka związanego z tym, że nie dojdzie na tej drodze do przerwania biegu przedawnienia, z ostrożności nie powinien składać wniosku o przeprowadzenie mediacji, jeśli niewiele czasu pozostało do końca terminu przedawnienia przysługującego mu roszczenia (wówczas trzeba by bowiem uwzględnić czas pomiędzy złożeniem wniosku a przystapieniem przez przewodniczącego do jego oceny formalnej, a w razie wezwania do uzupełnienia braków - czas doręczenia takiego wezwania, tydzień na uzupełnienie tych braków, następnie czas na doręczenie wniosku mediatorowi i drugiej stronie oraz jeszcze tydzień wymagany na gruncie art. $183^{6}$ pkt 1-3 k.p.c., względnie czas na odmowę zgody na mediację w myśl art. $183^{6}$ pkt 4 k.p.c.). Z tego względu mogłoby to obniżyć popularność korzystania z mediacji pod koniec terminu przedawnienia roszczeń (co nie stanowiłoby jednak jakiejśs drastycznej zmiany, gdyż jak wcześniej wskazano, w pewnym zakresie zjawisko to zachodzi też na gruncie obecnie obowiąującej regulacji).

Tak daleko idące wątpliwości co do momentu, w którym dochodzi do przerwania biegu przedawnienia, nie zachodzą natomiast w przypadku, kiedy do mediacji kieruje strony sąd. Ustawodawca przewidział bowiem możliwość skierowania stron do mediacji przez sąd już w trakcie postępowania, aż do zakończenia pierwszego posiedzenia wyznaczonego na rozprawę, a po zamknięciu tego posiedzenia - tylko na zgodny wniosek stron (art. $183^{8} \S 1$ k.p.c.). Trzeba więc zauważyć, że najpierw dochodzi tu do zainicjowania postępowania przez stronę i już np. wniesienie pozwu powoduje przerwanie biegu przedawnienia roszczenia (art. $123 \S 1$ pkt 1 k.c.), a przy tym przedawnienie nie biegnie na nowo, dopóki postępowanie to nie zostanie zakończone (art. 124 $\S 2$ k.c.). Wydanie więc w jego trakcie przez sąd postanowienia o skierowaniu stron do mediacji nie stanowi w takim stanie rzeczy zdarzenia, które powodowałoby przerwanie biegu przedawnienia; wszak termin ten został już uprzednio przerwany wniesieniem pozwu i obecnie w trakcie trwania zainicjowanego w ten sposób postępowania nie biegnie. Zwłaszcza że sposób proceduralnego ujęcia inicjowania mediacji postanowieniem sądu sprawia, że nie jawi się ona jako całkowicie oderwana od sprawy zapoczątkowanej pozwem strony. Przemawia za tym m.in. to, że w razie braku wyrażenia przez którąś ze stron zgody na mediację przewodniczący wyznacza rozprawę ${ }^{25}$ (art. $183^{10} \S 2$ k.p.c.), a z kolei w przypadku odbycia mediacji protokół sporządzony z jej przebiegu podle-

${ }^{25}$ Co stanowi przejaw zasady dobrowolności mediacji. Zob. E. Stefańska, w: M. Manowska (red.), Kodeks postępowania cywilnego. Komentarz, t. 1: Art. 1-505 $5^{37}$, Warszawa 2011, s. 381; P. Sobolewski, Mediacja w sprawach cywilnych, „Przegląd Prawa Handlowego” 2006, nr 2, s. 33. 
ga złożeniu w sądzie (art. $183^{13} \S 2$ k.p.c.). Celem nadania ugodzie zawartej przed mediatorem mocy prawnej ugody zawartej przed sądem, ugoda zawarta w toku mediacji musi zostać zatwierdzona przez sąd, przy czym podlega merytorycznej ocenie tego ostatniego (art. $183^{14}, 183^{15}$ k.p.c.) ${ }^{26}$. Dopiero w razie zawarcia ugody i jej zatwierdzenia przez sąd ten ostatni wyda postanowienie o umorzeniu postępowania. Ponadto przeciwko uznaniu, że w wyniku postanowienia sądu o skierowaniu stron do mediacji dochodzi do przerwania biegu przedawnienia, przemawia to, że jest to czynność podejmowana przez sąd, a nie wierzyciela lub dłużnika, podczas gdy działaniom tylko tych dwóch ostatnich podmiotów, jako tych, których interesów istnienie roszczenia i jego dochodzenie bezpośrednio dotyczy, ustawodawca przypisuje prawnie relewantne znaczenie w odniesieniu do przerywania biegu przedawnienia roszczeń (tak jak i w art. $123 \S 1$ pkt 1 i 2 k.c.).

dr Joanna Kuźmicka-Sulikowska

Uniwersytet Wroctawski

joanna.kuzmicka-sulikowska@uwr.edu.pl

\section{INTERRUPTION OF THE RUNNING OF THE LIMITATION PERIOD OF CLAIMS BY INITIATING MEDIATION}

Sum mary

The article addresses the issue of interrupting the running of the limitation period through the initiation of mediation. First, this issue is analysed in the context of other circumstances provided for in the Civil Code, which may interrupt the running of the limitation period but frequently provoke controversy. These examples are used to demonstrate that interpretative difficulties arise in respect of the initiation of mediation proceedings as well, as an event interrupting the running of the limitation period. Such difficulties are primarily due to the fact that while Article $183^{6} \S 1$ of the Code of Civil Procedure (CCP) states that mediation proceedings are initiated from the moment one of the parties serves the mediator with a petition to conduct mediation proceedings, there is no regulation addressing the matter of formal defects in the petition; legal scholars take diametrically opposing positions in respect of whether it is possible to remedy these defects and initiate the mediation process, and whether the running of the limitation period can thereby be interrupted. In addition, Article $183^{6} \S 2 \mathrm{CCP}$ is another source of uncertainty as it provides for a range of circumstances in which the proper serving of the petition does not lead to the initiation of mediation proceedings. The article subjects these regulations to thorough analysis, with particular attention paid to the impact of these situations on interruption of the limitation period on claims (including assessment of the justifiability of such legal solutions and with reference to the views of scholars, as well as de lege ferenda remarks). Mention is also made of issues associated with the limitation period in cases where the court directs the parties to engage in mediation.

${ }^{26}$ Jeśli ugoda podlega wykonaniu w drodze egzekucji, sad zatwierdza ją przez nadanie klauzuli wykonalności (zob. R. Schmidt, Nadanie klauzuli wykonalności ugodzie zawartej przed mediatorem, „ADR. Arbitraż i Mediacja” 2010, nr 1, s. 139-164). 